\title{
Manufacture of Fior di Latte cheese by incorporation of probiotic lactobacilli
}

\author{
F. Minervini, ${ }^{*}$ S. Siragusa, ${ }^{*}$ M. Faccia, ${ }^{*}$ F. Dal Bello, $\dagger$ M. Gobbetti, ${ }^{*}$ and M. De Angelis ${ }^{\star 1}$ \\ *Department of Biologia e Chimica Agro-Forestale ed Ambientale, University of Bari, Aldo Moro, 70126, Italy \\ †Clerici-Sacco Group, Como, I-22071, Italy
}

\section{ABSTRACT}

This work aimed to select heat-resistant probiotic lactobacilli to be added to Fior di Latte (high-moisture cow milk Mozzarella) cheese. First, 18 probiotic strains belonging to Lactobacillus casei, Lactobacillus delbrueckii ssp. bulgaricus, Lactobacillus paracasei, Lactobacillus plantarum, Lactobacillus rhamnosus, and Lactobacillus reuteri were screened. Resistance to heating $\left(65\right.$ or $55^{\circ} \mathrm{C}$ for $\left.10 \mathrm{~min}\right)$ varied markedly between strains. Adaptation at $42^{\circ} \mathrm{C}$ for $10 \mathrm{~min}$ increased the heat resistance at $55^{\circ} \mathrm{C}$ for $10 \mathrm{~min}$ of all probiotic lactobacilli. Heat-adapted L. delbrueckii ssp. bulgaricus SP5 (decimal reduction time at $55^{\circ} \mathrm{C}$ of $227.4 \mathrm{~min}$ ) and $L$. paracasei BGP1 (decimal reduction time at $55^{\circ} \mathrm{C}$ of 40.8 min) showed the highest survival under heat conditions that mimicked the stretching of the curd and were used for the manufacture of Fior di Latte cheese. Two technology options were chosen: chemical (addition of lactic acid to milk) or biological (Streptococcus thermophilus as starter culture) acidification with or without addition of probiotics. As determined by random amplified polymorphic DNA-PCR and 16S rRNA gene analyses, the cell density of L. delbrueckii ssp. bulgaricus SP5 and L. paracasei BGP1 in chemically or biologically acidified Fior di Latte cheese was approximately $8.0 \log _{10}$ $\mathrm{cfu} / \mathrm{g}$. Microbiological, compositional, biochemical, and sensory analyses (panel test by 30 untrained judges) showed that the use of $L$. delbrueckii ssp. bulgaricus SP5 and L. paracasei BGP1 enhanced flavor formation and shelf-life of Fior di Latte cheeses.

Key words: Fior di Latte cheese, probiotic lactobacilli

\section{INTRODUCTION}

Functional microorganisms and health benefits represent a combination with great potential for fermented functional foods (Gobbetti et al., 2010). Several health benefits are claimed for foods containing probiotic microorganisms, especially lactobacilli and bifidobacteria (Candela et al., 2010). Recent reports highlight

Received January 5, 2011.

Accepted October 14, 2011

${ }^{1}$ Corresponding author: m.deangelis@agr.uniba.it benefits and limitations under various medical and health-related areas: (1) control of intestinal inflammation and therapeutic role in gastroenterology (Bai and Ouyang, 2006); (2) maintenance of remission in Crohn disease (Rolfe et al., 2006); (3) improvement of human health and control of antibiotic-related diarrhea (Kramer and Bischoff, 2006); (4) control of infections during pregnancy and prevention of urinary tract infections (Falagas et al., 2006); (5) management of allergic diseases (Boyle and Tang, 2006); and (6) several other medical applications (O'Flaherty and Klaenhammer, 2010). The minimum cell density of probiotic microorganisms that has to be contained in a food product to exert a beneficial effect is debated (Reid, 2008). The Fermented Milks and Lactic Acid Bacteria Beverages Association in Japan stipulates that the minimum density of viable bifidobacteria in a probiotic food should range from 6.0 to $7.0 \log _{10} \mathrm{cfu} / \mathrm{g}$ or $\mathrm{mL}$ (Gardiner et al., 1999; Vinderola et al., 2000). Several factors affect the loss of viability of probiotics in foods, including acidity, postacidification, level of oxygen and oxygen permeation through the package, sensitivity to antimicrobial substances synthesized by starter bacteria, and lack of nutrients (De Angelis and Gobbetti, 2004; Fortin et al., 2011).

Fermented milks have long been used as the main vehicles for probiotic strains. Less frequently, cheeses have been used for incorporation of probiotic microorganisms, but they may offer a number of advantages compared with fermented milks (Fortin et al., 2011). Probiotic lactobacilli and bifidobacteria have been added to several cheese varieties such as cottage cheese (O'Riordan and Fitzgerald, 1998), Kasar (Özer et al., 2008), Canestrato Pugliese (Corbo et al., 2001), Gouda (Gomes et al., 1995), Crescenza (Gobbetti et al., 1998), goat milk cheeses (Gomes and Malcata, 1998), Argentinean (Bergamini et al., 2005), and Cheddar (Gardiner et al., 1999; Ong et al., 2007).

To the best of our knowledge, no studies have considered the potential of incorporating probiotic bacteria (Lactobacillus or Bifidobacterium spp.) in pasta filata cheeses such as Mozzarella. In Italy, Fior di Latte (highmoisture cow milk Mozzarella) cheese is recognized as a Guaranteed Traditional Specialty. This cheese is manufactured throughout Italy using mainly cow milk 
(De Angelis and Gobbetti, 2011). Fior di Latte cheese is manufactured through chemical acidification of the curd or using commercial (Streptococcus thermophilus) or natural whey starter cultures. Several challenges are related to the addition of probiotics to Fior di Latte cheese, the most important being the survival of probiotic bacteria during cheese making and storage (De Angelis and Gobbetti, 2004; Fortin et al., 2011). Another challenge is maintaining the sensory attributes of the cheese (Bruhn et al., 2002; Bergamini et al., 2009; Vinderola et al., 2009).

This paper aimed to select heat-resistant probiotic lactobacilli and establish a protocol for the manufacture of Fior di Latte cheese that guarantees high survival of probiotic lactobacilli.

\section{MATERIALS AND METHODS}

\section{Strains and Growth Conditions}

Probiotic strains Lactobacillus casei BGP93; Lactobacillus delbrueckii ssp. bulgaricus SP5; Lactobacillus paracasei LPC01, BGP1, and BGP2; Lactobacillus plantarum BG112, BGP12, LP27, LP32, LP33, LP35, LP36, LP39, LP40, LP42, and LP47; Lactobacillus rhamnosus SP1; and Lactobacillus reuteri DSM17938, isolated from the human gastrointestinal tract, were supplied by Sacco S.r.l. (Cadorago, Italy). Strains were propagated for $24 \mathrm{~h}$ at $37^{\circ} \mathrm{C}$ in de Man, Rogosa, and Sharpe broth (MRS; Oxoid, Basingstoke, UK). Most of these strains, SP5 and BGP1 included, showed antimicrobial activity toward human pathogens (Escherichia coli ATCC 43887, Salmonella enterica ssp. enterica ATCC 9184). As shown by in vivo test, all strains survived gastrointestinal transit and adhered to human intestinal mucosa. Some strains, SP5 and BGP1 included, were commercially available in the probiotics catalog of Sacco S.r.l.

\section{Heat Resistance}

Lactobacillus strains were cultivated in MRS broth at the optimum temperature until they reached the stationary phase of growth (18 h; optical density at 620 $\mathrm{nm}=2.45)$. Cells were harvested by centrifugation at $9,000 \times g$ for $10 \mathrm{~min}$ at $4^{\circ} \mathrm{C}$, washed twice with $50 \mathrm{mM}$ sterile potassium phosphate buffer ( $\mathrm{pH}$ 7.0), and resuspended in sterile distilled water at an optical density at $620 \mathrm{~nm}$ of 2.45 (corresponding to $9.4 \log _{10} \mathrm{cfu} / \mathrm{g}$ ). Suspensions were centrifuged $(9,000 \times g$ for $10 \mathrm{~min}$ at $4^{\circ} \mathrm{C}$ ) and the cells resuspended in reconstituted skim milk (Oxoid) to a final cell density of $9.4 \log _{10} \mathrm{cfu} / \mathrm{g}$. Samples $(0.5 \mathrm{~mL})$ were transferred to capillary glass tubes (catalog no. 0893.01830, Carlo Erba Reagenti,
Milan, Italy) and heated in a water bath at 55 or $65^{\circ} \mathrm{C}$ for $10 \mathrm{~min}$. After heat treatment, samples were chilled on ice for $5 \mathrm{~min}$, diluted, plated on MRS agar, and incubated at $37^{\circ} \mathrm{C}$ for 48 to $96 \mathrm{~h}$. Each experiment was carried out in triplicate, and the average and standard deviation were calculated.

\section{Heat Adaptation}

Lactobacillus strains were harvested at stationary phase $(18 \mathrm{~h})$, washed, and resuspended in reconstituted skim milk at the final density of $9.4 \log _{10} \mathrm{cfu} / \mathrm{g}$ (see above). To induce heat adaptation, cell suspensions were incubated for 20,30,40, and $60 \mathrm{~min}$ at 42,45 , or $48^{\circ} \mathrm{C}$. Control cells were incubated for $20,30,40$, and $60 \mathrm{~min}$ at $37^{\circ} \mathrm{C}$. After incubation, control and adapted cells were treated at $55^{\circ} \mathrm{C}$ for $10 \mathrm{~min}$. After heat treatment, cultivable cells were enumerated on MRS agar. The decimal reduction time ( $\mathbf{D}$-value, the time taken to reduce the cell numbers by $1 \log _{10}$ cycle) was calculated after heat treatment at $55^{\circ} \mathrm{C}$ for 5 to $120 \mathrm{~min}$. The values reported are means from at least 3 separate experiments. Adapted cells of the strains with the highest heat resistance (SP5 and BGP1) were cultivated at $42^{\circ} \mathrm{C} 3$ times. Each time $\left(18 \mathrm{~h}\right.$ at $\left.42^{\circ} \mathrm{C}\right)$, the cells were treated at $55^{\circ} \mathrm{C}$ for $10 \mathrm{~min}$ and survival was evaluated as described above.

\section{Manufacture of Fior di Latte Cheese}

Fior di Latte cheese was manufactured from cow milk that was pasteurized at $72^{\circ} \mathrm{C}$ for $15 \mathrm{~s}$. Four types of Fior di Latte cheese were manufactured, as follows: (1) chemical acidification with $1.45 \mathrm{~g} / \mathrm{L}$ (wt/vol) lactic acid (chemically acidified Mozzarella, CAM); (2) chemical acidification with lactic acid and addition of selected probiotic strains: L. delbrueckii ssp. bulgaricus SP5, L. paracasei BGP1, or both (chemically acidified Mozzarella with probiotics, CAMP); (3) biological acidification with commercial starter culture (Streptococcus thermophilus, Sacco S.r.l.; biologically acidified Mozzarella, BAM); or (4) biological acidification with commercial starter culture and addition of selected probiotic lactobacilli strains: SP5, or BGP1, or both (biologically acidified Mozzarella with probiotics, BAMP). Selected probiotic lactobacilli strains were cultivated in MRS broth using a 20-L bioreactor Diaferm 20 (Diachrom SA, Mendrisio, Switzerland). After growth, cells were harvested by centrifugation $(9,000 \times$ $g$ for $10 \mathrm{~min}$ at $4^{\circ} \mathrm{C}$ ), washed twice with sterile $50 \mathrm{mM}$ potassium phosphate buffer ( $\mathrm{pH} 7.0)$, resuspended in sterile reconstituted skim milk, and subjected to heat adaptation as described above. Afterward, adapted $L$. delbrueckii ssp. bulgaricus SP5 and L. paracasei BGP1 
were added, singly or in combination, to the curd in the last phase of curd ripening at a cell density of 8.0 or $9.0 \log _{10} \mathrm{cfu} / \mathrm{g}$, respectively. In detail, the adapted cells (10.0 or $11.0 \log _{10} \mathrm{cfu} / \mathrm{g}$ of milk) were added to curd at $1 \%$ and mixed for 5 min at room temperature. The difference in the inocula between strains reflected their different heat resistance. Cheese making was carried by Sanguedolce S.r.l. (Andria, Italy), using the protocol described by De Angelis et al. (2008), with some modifications. Stretching of the curd was performed over 10 min at $80^{\circ} \mathrm{C}$ (core temperature of the curd of $55^{\circ} \mathrm{C}$ ). The integration of the cells into the food matrix was evaluated through microbiological analyses (see below) and identification of isolates (see below) of a significant number of curd samples before final stretching. Each type of Fior di Latte cheese was manufactured in triplicate.

\section{Microbiological Analysis}

Twenty grams of cheese sample was diluted in 180 $\mathrm{mL}$ of sodium citrate $(2 \%, \mathrm{wt} / \mathrm{vol})$ solution and homogenized with a Stomacher Laboratory Blender 400 (PBI International, Milan, Italy). Serial decimal dilutions of homogenates were made in quarter-strength Ringer's solution and plated on the following specific media (Oxoid) for viable counts: MRS agar for mesophilic and thermophilic lactobacilli at $25^{\circ} \mathrm{C}$ and $42^{\circ} \mathrm{C}$ for 48 $\mathrm{h}$ under anaerobiosis, respectively; Slanetz and Bartley agar for enterococci at $37^{\circ} \mathrm{C}$ for $48 \mathrm{~h}$; M17 agar for streptococci at $37^{\circ} \mathrm{C}$ for $48 \mathrm{~h}$; and violet red bile lactose agar for total and fecal coliforms at $37^{\circ} \mathrm{C}$ and $44^{\circ} \mathrm{C}$ for $24 \mathrm{~h}$, respectively. To enumerate the selected probiotic lactobacilli added to cheese, diluted samples were also plated on a differential MRS agar medium containing vancomycin $(20 \mathrm{mg} / \mathrm{L}$, wt/vol). This medium allowed determination of the cell density of $L$. paracasei BGP1. Cell density of L. delbrueckii ssp. bulgaricus SP5 was inferred by subtracting the cell density of BGP1 from that of total lactobacilli on MRS agar. To validate the values of cell density of each probiotic strain, further analyses were carried out.

\section{Isolation and Identification of Mesophilic and Thermophilic Lactobacilli}

Twenty colonies of presumptive mesophilic or thermophilic lactobacilli, possibly with different morphologies, were isolated from the highest plate dilutions of CAMP or BAMP curd or cheeses, either with a single probiotic strain (SP5 or BGP1) added or with a combination of probiotic lactobacilli (SP5 and BGP1) added (Baruzzi et al., 2000). Gram-positive, catalase-negative, nonmotile rod isolates were cultivated in MRS at 30 or $42^{\circ} \mathrm{C}$ for $24 \mathrm{~h}$ and restreaked into MRS agar. All the isolates considered for further analyses showed the capacity to acidify the culture medium. Microbial cultures were stored at $-20^{\circ} \mathrm{C}$.

Genomic DNA from presumptive lactobacilli isolates was extracted from 2-mL samples of each culture grown overnight at $30^{\circ} \mathrm{C}$ in MRS broth as described by De Angelis et al. (2006). The isolates were typed by random amplified polymorphic DNA (RAPD)-PCR using 3 oligonucleotides (M13: 5'-GAGGGTGGCGGTTCT-3', P4: 5'-CCGCAGCGTT-3', and P7: 5'-AGCAGCGTGG- $\left.3^{\prime}\right)$. The reaction mixture and PCR conditions were performed according to De Angelis et al. (2001). The RAPD-PCR patterns obtained were acquired by Gel Doc EQ System (Bio-Rad Laboratories, Hercules, CA) and compared using Fingerprinting II Informatix Software (Bio-Rad Laboratories).

The isolates were also identified at the species level by partial sequencing (at least $700 \mathrm{bp}$ ) of the DNA region coding for the $16 \mathrm{~S}$ rRNA gene, performed according to a method described elsewhere (De Angelis et al., 2006). The sequences were compared with known sequences reported in GenBank using the basic local alignment search tool (BLAST) program (http://www. ncbi.nlm.nih.gov/blast).

\section{Compositional Analysis}

Moisture was determined as reported by the International Dairy Federation (IDF, 1970). The $\mathrm{pH}$ was determined by direct insertion of a Foodtrode (Hamilton, Bonaduz, Switzerland) electrode. Soluble and total N were determined by the micro-Kjeldahl method (Kuchroo and Fox, 1982). Concentrations of carbohydrates (glucose, lactose, and galactose) and organic acids were determined by HPLC using an ÄKTA Purifier System (GE Healthcare Bio-Sciences, Uppsala, Sweden) equipped with a $300-\mathrm{mm} \times 7.8$-mm internal diameter cation exchange column (Aminex HPX-87H, Bio-Rad Laboratories). Elution was carried out isocratically at $60^{\circ} \mathrm{C}$, with a flow rate of $0.3 \mathrm{~mL} / \mathrm{min}$, using $10 \mathrm{mM}$ $\mathrm{H}_{2} \mathrm{SO}_{4}$ as mobile phase. Carbohydrates were detected using a Perkin Elmer 200a refractive index detector (Perkin-Elmer Corp., Waltham, MA), whereas organic acids were detected by a UV detector at an absorbance of $210 \mathrm{~nm}$ (Zeppa et al., 2001). Carbohydrates and organic acids used as standards were purchased from Sigma Chemical Co. (Milan, Italy).

\section{Assessment of Proteolysis and Concentration of Free AA}

The $\mathrm{pH}$ 4.6-soluble and insoluble extracts of Fior di Latte cheeses were obtained as described by Kuchroo 
and Fox (1982). The pH 4.6-insoluble fractions were analyzed by urea-PAGE using a Protean II xi vertical slab gel unit (Bio-Rad Laboratories) and the stacking gel system. Gels were stained by the method of Blakesley and Boezi (1977) with Coomassie Brilliant Blue G250, destained in distilled water, and scanned on a flatbed scanner (Epson Perfection 4180 Photo, Seiko Epson Corp., Nagano, Japan). The peptide profiles of the $\mathrm{pH}$ 4.6-soluble fractions were determined by reverse-phase (RP)-HPLC with a Resource RPC column using an ÄKTA Purifier System (GE Healthcare Bio-Sciences). Total and individual free AA (FAA) were analyzed by a Biochrom 30 series Amino Acid Analyzer (Biochrom Ltd., Cambridge, UK; De Angelis et al., 2008). Thirty grams of cheese was suspended in $90 \mathrm{~mL}$ of $50 \mathrm{mM}$ phosphate buffer $\mathrm{pH} 7.0$ and mixed for 10 min by Stomacher (PBI International). The suspension was kept at $40^{\circ} \mathrm{C}$ for $1 \mathrm{~h}$ under gentle stirring $(150 \mathrm{rpm})$ and centrifuged at $3,000 \times g$ for $30 \mathrm{~min}$ at $4^{\circ} \mathrm{C}$. The $\mathrm{pH}$ of the extract was adjusted to 4.6. The suspension was centrifuged at $10,000 \times g$ for $10 \mathrm{~min}$. Proteins and peptides of the $\mathrm{pH}$ 4.6-soluble nitrogen fractions were precipitated by adding 5\% (wt/vol) cold solid sulfosalicylic acid, holding at $4^{\circ} \mathrm{C}$ for $1 \mathrm{~h}$, and centrifuging at $15,000 \times g$ for $15 \mathrm{~min}$. Amino acids used as standards were purchased from Sigma Chemical Co.

\section{Sensory Analysis}

The sensory analysis of Fior di Latte cheeses was carried out using the descriptive model of Coppola et al. (1990) with a few modifications (De Angelis et al., 2008). Before the sensory analysis, an untrained panel consisting of 30 judges was preliminarily briefed on the use of the sensory attributes on a 4-point hedonic scale $(0-3)$ and a previously developed scorecard (Coppola et al., 1990). Statements for ideal intensity of flavor and body/texture, description of creamy and sour taste and bitter defect and their intensity scores were based on the typical expectations of local consumers for Fior di Latte cheese. In detail, a score of 3 for the "intensity of flavor" attribute was given to cheeses characterized by a bland and walnutty, fresh and odorous, slightly and pleasantly acid flavor; a score of 3 for the "creamy" attribute was given to cheeses characterized by a pleasantly fatty, creamy taste; a score of 3 for the "sour" attribute was given to cheeses characterized by a fundamental taste sensation of which lactic and citric acid are typical; and a score of 3 for the "body/texture" attribute was given to cheeses characterized by a flexible and elastic body and by a soft and smooth texture. Scores were classified as preferable (3), barely acceptable (2), needs modification (1), and not acceptable (0). The "bitter" defect, defined as a taste sensation perceived at the back of the tongue resembling the taste of caffeine or quinine, was evaluated, and given a score of 3 in the absence of the perception. Scores for bitter defect were classified as preferable (0), barely acceptable (1), needs modification (2), and not acceptable (3).

Cheeses were taken out of the refrigerator $1 \mathrm{~h}$ before serving. Just before testing, they were taken out of the the aqueous solution used for high moisture Mozzarella storage, cut into slices (approximately $2.5 \times 2.5 \mathrm{~cm}$ ), and placed in plastic cups. Cheeses were randomized to avoid positional bias. Duplicate trays of samples were presented at 10-min intervals to the panel.

\section{Statistical Analysis}

Experimental data were subjected to ANOVA. The mean values of each treatment were compared by Tukey's procedure at $P<0.05$ using the software package Statistica (Statistica 6.0 for Windows 1998; StatSoft Inc., Tulsa, OK). Multivariate statistical analysis and principal components analysis (PCA) were carried out using Statistica (StatSoft Inc.).

\section{RESULTS}

\section{Heat Resistance of Probiotic Lactobacilli}

The first criterion for selecting probiotic lactobacilli was resistance to heat treatments $\left(55\right.$ and $65^{\circ} \mathrm{C}$ for 10 min) that mimic conditions used during stretching of the curd. After treatment at $65^{\circ} \mathrm{C}$ for $10 \mathrm{~min}$, survival varied markedly between species and strains (Figure 1). Viable cells ranged from $5.5 \pm 0.18$ (L. casei BGP93) to $6.98 \pm 0.23 \log _{10} \mathrm{cfu} / \mathrm{g}$ (L. delbrueckii ssp. bulgaricus SP5). As expected, cell survival after treatment at $55^{\circ} \mathrm{C}$ for $10 \mathrm{~min}$ increased markedly compared with treatment at $65^{\circ} \mathrm{C}$. The highest values were found for strains L. delbrueckii ssp. bulgaricus SP5 (9.08 \pm 0.24 $\left.\log _{10} \mathrm{cfu} / \mathrm{g}\right)$, L. paracasei BGP1 and BGP2 (8.76 \pm 0.15 and $8.45 \pm 0.20 \log _{10} \mathrm{cfu} / \mathrm{g}$, respectively), L. plantarum BGP12 and LP40 $\left(8.19 \pm 0.24\right.$ and $8.42 \pm 0.18 \log _{10}$ cfu/g, respectively), and L. rhamnosus SP1 (8.37 \pm 0.17 $\left.\log _{10} \mathrm{cfu} / \mathrm{g}\right)$. The other probiotic lactobacilli showed decreases in cell number greater than $1 \log _{10}$ cycle.

To induce heat adaptation, probiotic lactobacilli were previously subjected to adaptation at different times (20, 30, 40, and $60 \mathrm{~min})$ and temperatures (42, 45, and $48^{\circ} \mathrm{C}$ ). The greatest survival was found when cells were adapted at $42^{\circ} \mathrm{C}$ for $30 \mathrm{~min}$. During treatment at $55^{\circ} \mathrm{C}$ for $10 \mathrm{~min}$, adapted cells increased survival from 0.30 to $0.85 \log _{10} \mathrm{cfu} / \mathrm{g}$ (Figure 1). Under these conditions, L. delbrueckii ssp. bulgaricus SP5 did not show a decrease in cell number. Adapted L. paracasei BGP1 and BGP2 showed a slight decrease $\left(<0.5 \log _{10}\right.$ cycle). 

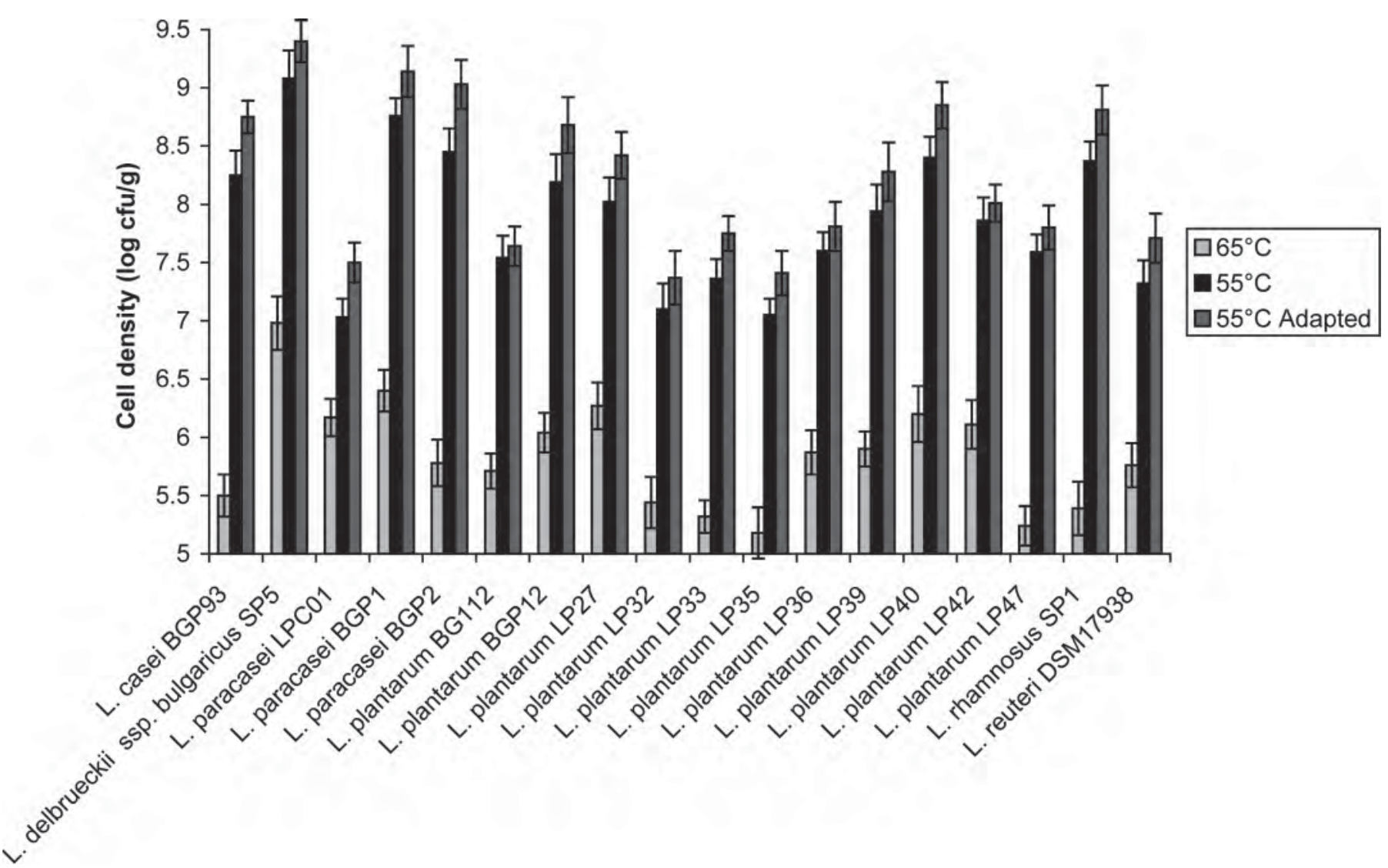

Figure 1. Survival $\left(\log _{10} \mathrm{cfu} / \mathrm{g}\right)$ of probiotic lactobacilli. Cells were suspended in reconstituted skim milk at cell density of $9.4 \log _{10} \mathrm{cfu} / \mathrm{g}$ and subjected to the following heat treatments: $65^{\circ} \mathrm{C}$ for $10 \mathrm{~min}$ (light gray rectangles), $55^{\circ} \mathrm{C}$ for 10 min (black rectangles), and $42^{\circ} \mathrm{C}$ for 30 min (adaptation) and further $55^{\circ} \mathrm{C}$ for $10 \mathrm{~min}$ (dark gray rectangles). L. $=$ Lactobacillus.

Similar results were found during treatment at $65^{\circ} \mathrm{C}$ for 10 min (data not shown). The decimal reduction time at $55^{\circ} \mathrm{C}\left(\mathbf{D}_{55}\right.$ value $)$ of adapted cells was determined for those strains that showed the greatest survival in order to select probiotic lactobacilli capable of withstanding stretching of the curd at $55^{\circ} \mathrm{C}$. Representative thermal death curves are shown in Figure 2. Except for L. delbrueckii ssp. bulgaricus SP5, prolonged heat treatment caused a marked decrease in the number of viable cells. The $\mathrm{D}_{55}$ values for sensitive strains ranged from $10.2 \pm$ 0.3 to $3.79 \pm 0.3 \mathrm{~h}$ (Table 1 ). Based on these results, $L$. delbrueckii ssp. bulgaricus SP5 and L. paracasei BGP1 were selected as probiotics for incorporation during the manufacture of Fior di Latte cheese. To skip the adaptation step, adapted cells of SP5 and BGP1 were cultivated at high temperature $\left(42^{\circ} \mathrm{C}\right.$ for $\left.18 \mathrm{~h}\right)$. Compared with adapted cells grown at optimal temperature $\left(37^{\circ} \mathrm{C}\right.$ for $18 \mathrm{~h}$ ), cells grown at $42^{\circ} \mathrm{C}$ showed a lower survival after treatment at $55^{\circ} \mathrm{C}$ for $10 \mathrm{~min}$ (data not shown).

\section{Microbiological Analyses of Fior di Latte Cheese}

To obtain the highest survival of selected probiotic lactobacilli, stretching of the curd was carried out at $55^{\circ} \mathrm{C}$ instead of $65^{\circ} \mathrm{C}$. Viability of probiotic lactobacilli was assayed under 2 different cheese-making options: chemical acidification with lactic acid or biological acidification using the commercial starter Strep. thermophilus.

For Fior di Latte cheese with a combination of probiotic lactobacilli added, after $1 \mathrm{~d}$ of storage, numbers of presumptive thermophilic and mesophilic lactobacilli in CAM cheese were very low $(3.80 \pm 0.14$ and 3.74 $\pm 0.08 \log _{10} \mathrm{cfu} / \mathrm{g}$, respectively; Table 2). Streptococci and enterococci were not found. The CAM cheese contained $2.8 \pm 0.1 \log _{10} \mathrm{cfu} / \mathrm{g}$ of coliforms; the CAMP cheese (with addition of probiotics) had $8.0 \pm 0.1$ and $8.07 \pm 0.3 \log _{10} \mathrm{cfu} / \mathrm{g}$ of presumptive thermophilic and mesophilic lactobacilli, respectively. Coliforms were not found. When Strep. thermophilus was used as starter culture (BAM cheese), the number of presumptive streptococci was $8.5 \log _{10} \mathrm{cfu} / \mathrm{g}$, and coliforms were found at $1.2 \log _{10} \mathrm{cfu} / \mathrm{g}$. The cell density of presumptive thermophilic and mesophilic lactobacilli and enterococci did not differ from that found for CAM cheese. When vancomycin was added to MRS, only CAMP and BAMP contained $8.0 \log _{10} \mathrm{cfu} / \mathrm{g}$ of lactobacilli (data 
Table 1. Decimal reduction time at $55^{\circ} \mathrm{C}\left(\mathrm{D}_{55} \text { value }\right)^{1}$ of selected probiotic lactobacilli strains in reconstituted skim milk after adaptation at $42^{\circ} \mathrm{C}$ for $30 \mathrm{~min}$

\begin{tabular}{lc}
\hline Strain & $\begin{array}{c}\mathrm{D}_{55} \text { value } \\
(\mathrm{min})\end{array}$ \\
\hline Lactobacillus plantarum LP40 & $39.0 \pm 0.4^{\mathrm{c}}$ \\
Lactobacillus plantarum LP27 & $16.8 \pm 0.5^{\mathrm{g}}$ \\
Lactobacillus plantarum LP42 & $10.2 \pm 0.3^{\mathrm{i}}$ \\
Lactobacillus plantarum LP39 & $15.0 \pm 0.2^{\mathrm{h}}$ \\
Lactobacillus paracasei BGP12 & $27.6 \pm 0.2^{\mathrm{f}}$ \\
Lactobacillus paracasei BGP1 & $40.8 \pm 0.4^{\mathrm{b}}$ \\
Lactobacillus paracasei BGP2 & $39.6 \pm 0.5^{\mathrm{c}}$ \\
Lactobacillus delbrueckii Ssp. bulgaricus SP5 & $227.4 \pm 0.3^{\mathrm{a}}$ \\
Lactobacillus rhamnosus SP1 & $38.4 \pm 0.4^{\mathrm{d}}$ \\
\hline
\end{tabular}

${ }^{\mathrm{a}-\mathrm{i}}$ Values with different superscript letters differ $(P<0.05)$.

${ }^{1}$ Mean values $\pm \mathrm{SD}$ of triplicate experiments analyzed in duplicate.

not shown). Except for streptococci, similar cell counts were found between CAMP and BAMP. The number of presumptive thermophilic and mesophilic lactobacilli increased in CAM and BAM cheeses during $14 \mathrm{~d}$ of storage. Enterococci increased by $3.0 \log _{10} \mathrm{cfu} / \mathrm{g}$ in CAMP and BAMP cheeses. The addition of selected probiotic lactobacilli seemed to improve survival of streptococci in BAMP cheese. At the end of storage, the highest cell density of coliforms was found in CAM cheese. Similar results were observed for Fior di Latte cheeses with single (SP5 or BGP1) probiotic lactobacilli added (data not shown).

\section{Survival of Probiotics in Fior di Latte Cheese}

For each type of Fior di Latte cheese with probiotic lactobacilli added, isolates of presumptive mesophilic (20 colonies from MRS agar incubated at $25^{\circ} \mathrm{C}$ ) and

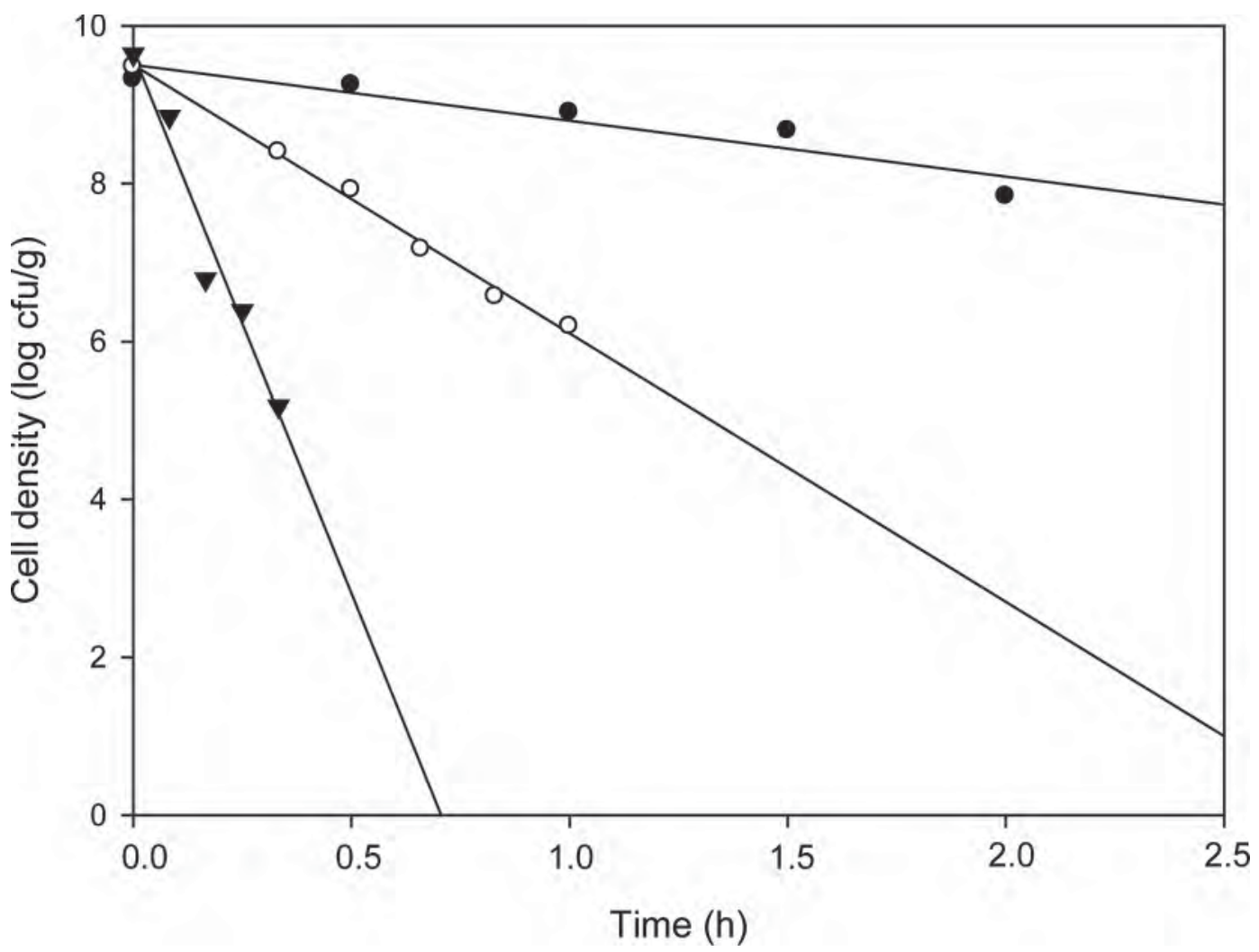

Figure 2. Representative rate of destruction curves of probiotic Lactobacillus delbrueckii ssp. bulgaricus SP5 (•), Lactobacillus paracasei BGP1 (O), and Lactobacillus plantarum LP42 ( $)$. Cells were suspended in reconstituted skim milk and subjected to adaptation at $42^{\circ} \mathrm{C}$ for 30 min and heat treatment at $55^{\circ} \mathrm{C}$ for $2 \mathrm{~h}$. 
thermophilic (20 colonies from MRS agar incubated at $42^{\circ} \mathrm{C}$ ) lactobacilli were subjected to RAPD-PCR analysis by using the single primers $\mathrm{P} 4, \mathrm{P} 7$, or M13. The patterns showed about 95 to $97 \%$ similarity, indicating the reproducibility of the technique under the conditions used (data not shown). The use of primer M13 clearly differentiated the RAPD patterns of selected probiotic lactobacilli from those of other strains isolated from CAMP or BAMP with the mixed cultures added. The identity of the isolates showing similar RAPD patterns to SP5 or BGP1 was confirmed by sequence analysis of at least $700 \mathrm{bp}$ of the $5^{\prime}$ region of the $16 \mathrm{~S}$ rRNA gene (data not shown). The cell density of SP5 and BGP1 in CAMP or BAMP was calculated as the number of colonies having the specific RAPD pattern. Regardless of their addition as single or mixed cultures, L. delbrueckii ssp. bulgaricus SP5 and L. paracasei BGP1 were integrated properly into the curd, as shown by the fact that their cell density (8.0 and $9.0 \log _{10} \mathrm{cfu} / \mathrm{g}$, respectively) was uniform between different curd samples. According to the $\mathrm{D}_{55}$ values, no decreased viability was found for L. delbrueckii ssp. bulgaricus SP5 during stretching of CAMP curd with the mixed culture added, whereas viability of $L$. paracasei BGP1 decreased by $1.0 \log _{10}$ $\mathrm{cfu} / \mathrm{g}$ (Figure 3). Consequently, both strains reached a final cell density of $8.0 \log _{10} \mathrm{cfu} / \mathrm{g}$ throughout storage. Cell viability of probiotics did not differ between CAMP and BAMP cheeses. Similar results were found for CAMP and BAMP cheeses with a single probiotic culture added (data not shown). When RAPD-PCR and partial sequencing of $16 \mathrm{~S}$ rRNA gene analyses were performed on isolates from MRS containing vancomycin, only BGP1 was found (data not shown). This result confirmed those found using isolates grown on nonselective MRS agar.

Following a preliminary panel, further experiments were carried out on CAMP and BAMP cheeses with the mixed cultures added, because their sensory attributes were better than those of the corresponding cheeses with one single probiotic culture added (data not shown).

\section{Compositional Analysis of Fior di Latte Cheese}

The gross composition of Fior di Latte cheeses varied markedly (Table 3). After $1 \mathrm{~d}$ of manufacture, all cheeses had moisture values ranging from 58.2 (BAMP) to $64.5 \%$ (CAM) (wt/wt). These values were typical of Fior di Latte cheese. The concentrations of protein and fat were in the typical range for Fior di Latte cheese. The BAM and BAMP cheeses had the highest values: $19.5 \%$ and $21.1 \%$ of protein and $17.0 \%$ and $18.0 \%$ of fat, respectively. These cheeses were also characterized by the lowest values of moisture and $\mathrm{pH}$. As ex-

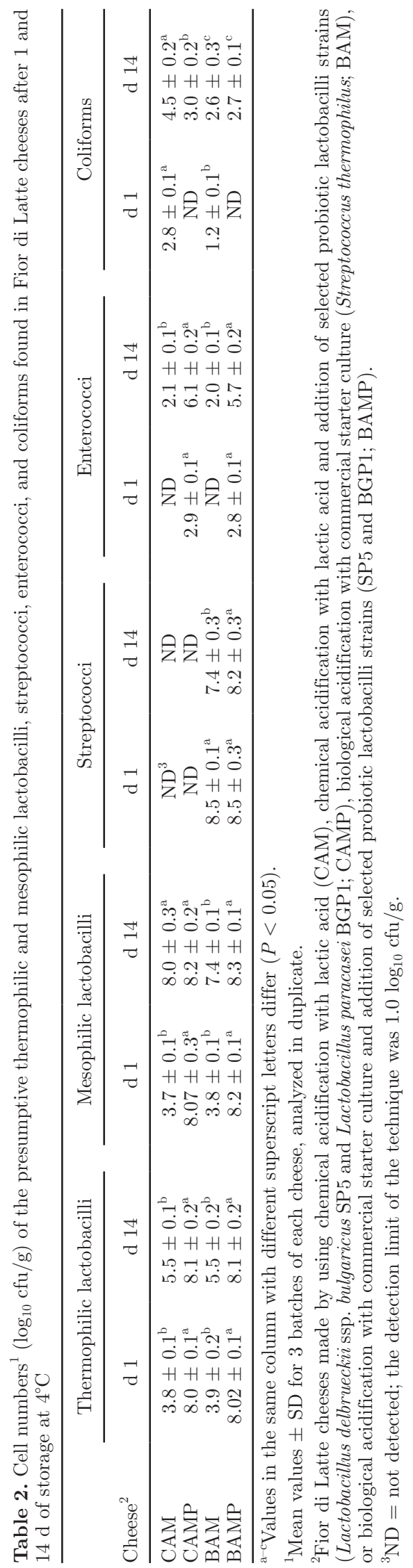




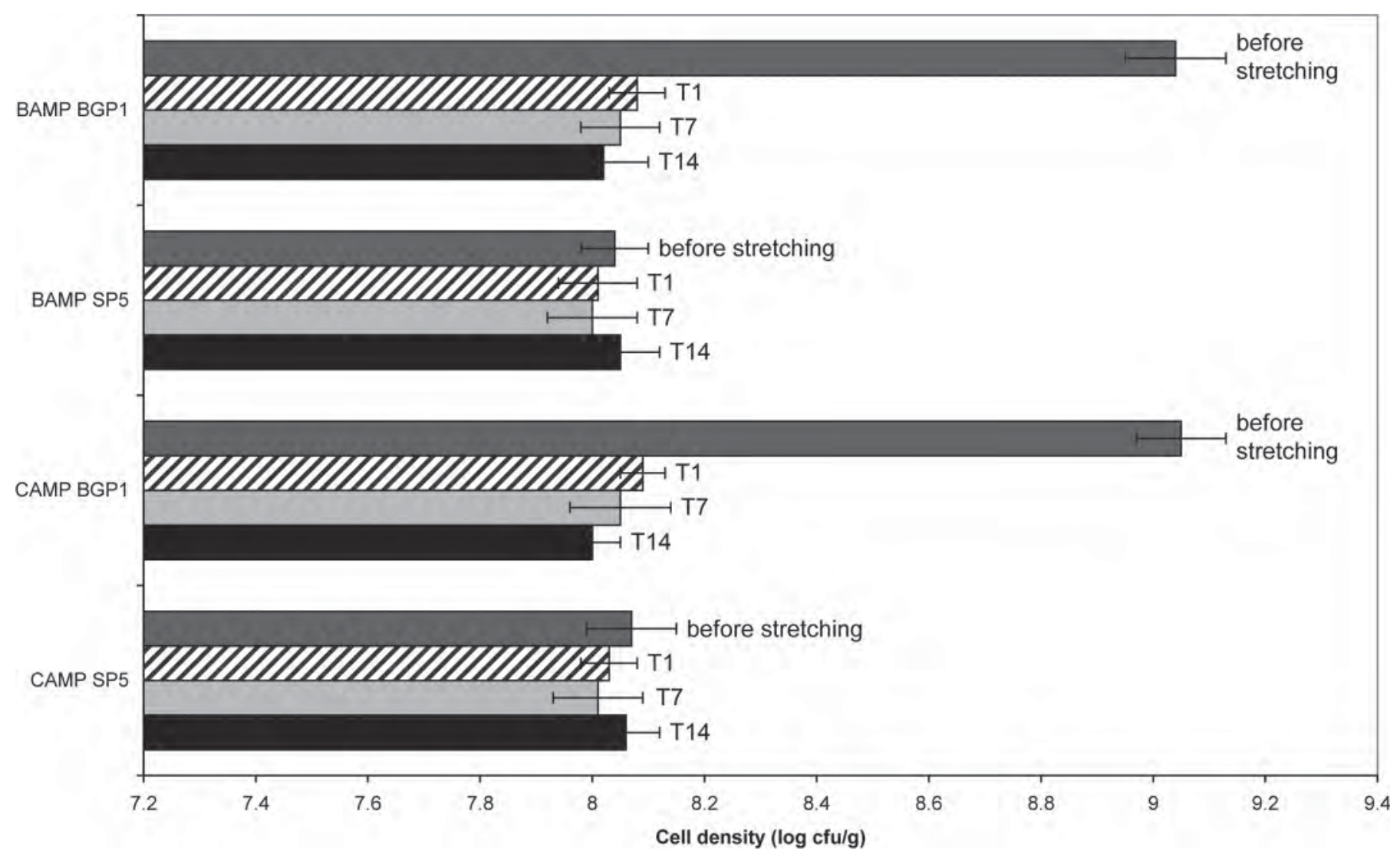

Figure 3. Cell numbers $\left(\log _{10} \mathrm{cfu} / \mathrm{g}\right)$ of probiotic Lactobacillus delbrueckii ssp. bulgaricus SP5 and Lactobacillus paracasei BGP1 before stretching of the curd, and in Fior di Latte cheeses after 1 (T1), 7 (T7), and 14 (T14) d of storage at $4^{\circ} \mathrm{C}$. Cheeses were manufactured by using direct acidification with lactic acid and addition of SP5 and BGP1 (CAMP) or commercial starter culture and addition of SP5 and BGP1 (BAMP).

pected, the most acidic Fior di Latte cheeses contained the highest concentration of lactic acid. The highest concentration of lactose was found in CAM cheese. In contrast, the highest concentrations of glucose and galactose were found in BAM cheese. Except for CAMP cheeses $(5.32 \pm 0.03)$, the $\mathrm{pH}$ did not significantly $(P>$ $0.05)$ decrease during storage. The $\mathrm{pH}$ values of BAM and BAMP increased to $5.55 \pm 0.01$ and $5.35 \pm 0.01$, respectively.

\section{Proteolysis of Fior di Latte Cheese}

After $1 \mathrm{~d}$ of storage, the level of $\mathrm{pH}$ 4.6-soluble nitrogen, expressed as percentage of total $\mathrm{N}$ in cheese, was in the range from 4.07 to $4.80 \%$ (Table 3). Compared with CAM cheese, all other cheeses had higher levels of $\mathrm{pH}$ 4.6-soluble nitrogen. During storage, the concentration of $\mathrm{pH} 4.6$-soluble nitrogen increased in all cheeses (5.10 to $5.56 \%$; data not shown). Urea-PAGE of the $\mathrm{pH}$ 4.6-insoluble $\mathrm{N}$ fraction showed progressive hydrolysis of $\alpha_{\mathrm{S} 1}-\mathrm{CN}$ and $\beta-\mathrm{CN}$ throughout storage. No detectable differences were found among the different cheeses (data not shown). The $\mathrm{pH}$ 4.6-soluble nitrogen fractions of Fior di Latte cheeses were analyzed by RP-HPLC, and quantitative and qualitative differences were evident between cheeses. After $1 \mathrm{~d}$ of manufacture, the highest total area of peaks was found for CAM, whereas only a few peak areas were found in CAMP. Overall, the number and areas of peaks increased during storage. The most complex peptide profiles were found in cheeses with the addition of selected probiotic lactobacilli (CAMP and BAMP; data not shown).

The highest concentration of FAA $1 \mathrm{~d}$ after manufacture was found in CAMP $(480.10 \pm 4.45 \mathrm{mg} / \mathrm{kg}$; Table 4). Overall, Glu, Phe, Lys, and Pro were the most abundant AA in CAM and CAMP Fior di Latte cheeses, whereas Phe, Arg, and Pro were the most abundant FAA in BAM and BAMP cheeses, respectively.

After $14 \mathrm{~d}$ of storage, the lowest concentrations of FAA were found in the absence of probiotics (154.39 \pm 3.70 and $127.12 \pm 3.84 \mathrm{mg} / \mathrm{kg}$ for CAM and BAM, respectively; Table 4). Compared with the initial values (on $\mathrm{d} 1$ ), the concentrations of FAA decreased in CAMP and increased in BAMP. In addition, the profiles of 
Table 3. Main values ${ }^{1}$ for the gross composition of Fior di Latte cheeses at $1 \mathrm{~d}$ of storage at $4^{\circ} \mathrm{C}$

\begin{tabular}{lcccc}
\hline & \multicolumn{4}{c}{ Cheese $^{2}$} \\
\cline { 2 - 5 } Item & CAM & CAMP & BAM & BAMP \\
\hline Moisture (\%,wt/wt) & $64.5^{\mathrm{a}} \pm 0.4$ & $61.9^{\mathrm{b}} \pm 0.7$ & $60.4^{\mathrm{c}} \pm 0.4$ & $58.2^{\mathrm{d}} \pm 0.5$ \\
Protein $(\%, w t / w \mathrm{w})$ & $16.4^{\mathrm{d}} \pm 0.7$ & $18.2^{\mathrm{c}} \pm 0.3$ & $19.5^{\mathrm{b}} \pm 0.5$ & $21.0^{\mathrm{a}} \pm 0.4$ \\
Fat $(\%, \mathrm{wt} / \mathrm{wt})$ & $15.5^{\mathrm{d}} \pm 0.2$ & $16.3^{\mathrm{c}} \pm 0.5$ & $17.0^{\mathrm{b}} \pm 0.3$ & $18.0^{\mathrm{a}} \pm 0.5$ \\
Ash $(\%, \mathrm{wt} / \mathrm{wt})$ & $1.6^{\mathrm{c}} \pm 0.06$ & $1.8^{\mathrm{b}} \pm 0.02$ & $1.8^{\mathrm{b}} \pm 0.03$ & $1.9^{\mathrm{a}} \pm 0.04$ \\
NaCl $(\%, \mathrm{wt} / \mathrm{wt})$ & $1.04^{\mathrm{a}} \pm 0.05$ & $1.07^{\mathrm{a}} \pm 0.06$ & $1.05^{\mathrm{a}} \pm 0.02$ & $1.03^{\mathrm{a}} \pm 0.05$ \\
$\mathrm{~N}(\%$ of total N) & $4.07^{\mathrm{d}} \pm 0.06$ & $4.20^{\mathrm{c}} \pm 0.04$ & $4.65^{\mathrm{b}} \pm 0.05$ & $4.80^{\mathrm{a}} \pm 0.04$ \\
$\mathrm{pH}$ & $5.7^{\mathrm{a}} \pm 0.02$ & $5.4^{\mathrm{b}} \pm 0.01$ & $5.1^{\mathrm{c}} \pm 0.02$ & $5.0^{\mathrm{cd}} \pm 0.01$ \\
Lactic acid $(\mathrm{m} M)$ & $6.0^{\mathrm{d}} \pm 0.5$ & $11.0^{\mathrm{c}} \pm 0.5$ & $20.0^{\mathrm{b}} \pm 0.4$ & $25.1^{\mathrm{a}} \pm 0.8$ \\
Lactose $(\mathrm{m} M)$ & $6.0^{\mathrm{a}} \pm 0.3$ & $5.0^{\mathrm{b}} \pm 0.2$ & $3.0^{\mathrm{c}} \pm 0.3$ & $3.0^{\mathrm{c}} \pm 0.4$ \\
Glucose $(\mathrm{m} M)$ & $0.0^{\mathrm{b}}$ & $0.0^{\mathrm{b}}$ & $4.0^{\mathrm{a}} \pm 0.2$ & $0.0^{\mathrm{b}}$ \\
Galactose $(\mathrm{m} M)$ & $4.0^{\mathrm{d}} \pm 0.5$ & $7.0^{\mathrm{c}} \pm 0.3$ & $12.0^{\mathrm{a}} \pm 0.4$ & $8.0^{\mathrm{b}} \pm 0.5$ \\
\hline
\end{tabular}

${ }^{\mathrm{a}-\mathrm{d}}$ Values in the same row with different superscript letters differ $(P<0.05)$.

${ }^{1}$ Mean values \pm SD for 3 batches of each cheese, analyzed in duplicate.

${ }^{2}$ Fior di Latte cheeses made by using chemical acidification with lactic acid (CAM), chemical acidification with lactic acid and addition of selected probiotic lactobacilli strains (Lactobacillus delbrueckii ssp. bulgaricus SP5 and Lactobacillus paracasei BGP1; CAMP), biological acidification with commercial starter culture (Streptococcus thermophilus; BAM), or biological acidification with commercial starter culture and addition of selected probiotic lactobacilli strains (SP5 and BGP1; BAMP).

individual FAA varied between cheeses. Histidine and Lys, and Val and His were the FAA found at the highest concentrations in CAM and BAM, respectively. The CAMP and BAMP cheeses contained high levels of Asp, Ala, Leu, Phe, and Orn. The FAA data were subjected to PCA using a covariance matrix (Figure 4). Principal component 1 showed the distribution of the cheeses according to the total concentration of FAA, whereas principal component 2 differentiated samples based on the relative differences among individual AA. After $1 \mathrm{~d}$ of storage, CAMP was clearly separated from the other cheeses by the high FAA concentration. Overall, the cheeses with Strep. thermophilus (BAM and BAMP) were located in the opposite zone from CAMP,

Table 4. Concentration $(\mathrm{mg} / \mathrm{kg})^{1}$ of individual and total free AA $(\mathrm{FAA})$ of the cheeses ${ }^{2}$ at 1 and $14 \mathrm{~d}$ of storage at $4^{\circ} \mathrm{C}$

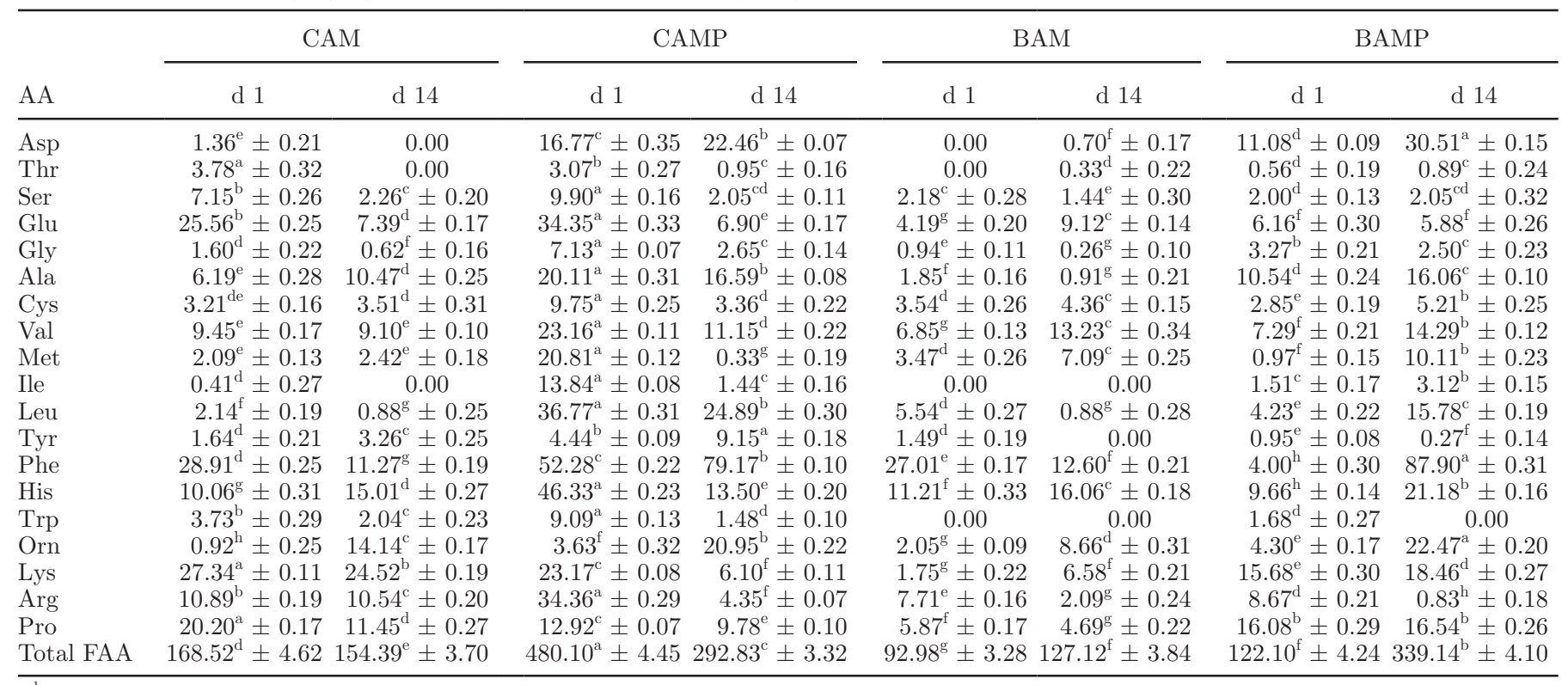

${ }^{\mathrm{a}-\mathrm{h}}$ Values in the same row with different superscript letters differ $(P<0.05)$.

${ }^{1}$ Mean values \pm SD for 3 batches of each cheese, analyzed in duplicate.

${ }^{2}$ Fior di Latte cheeses made by using chemical acidification with lactic acid (CAM), chemical acidification with lactic acid and addition of selected probiotic lactobacilli strains (Lactobacillus delbrueckii ssp. bulgaricus SP5 and Lactobacillus paracasei BGP1; CAMP), biological acidification with commercial starter culture (Streptococcus thermophilus; BAM), or biological acidification with commercial starter culture and addition of selected probiotic lactobacilli strains (SP5 and BGP1; BAMP). 


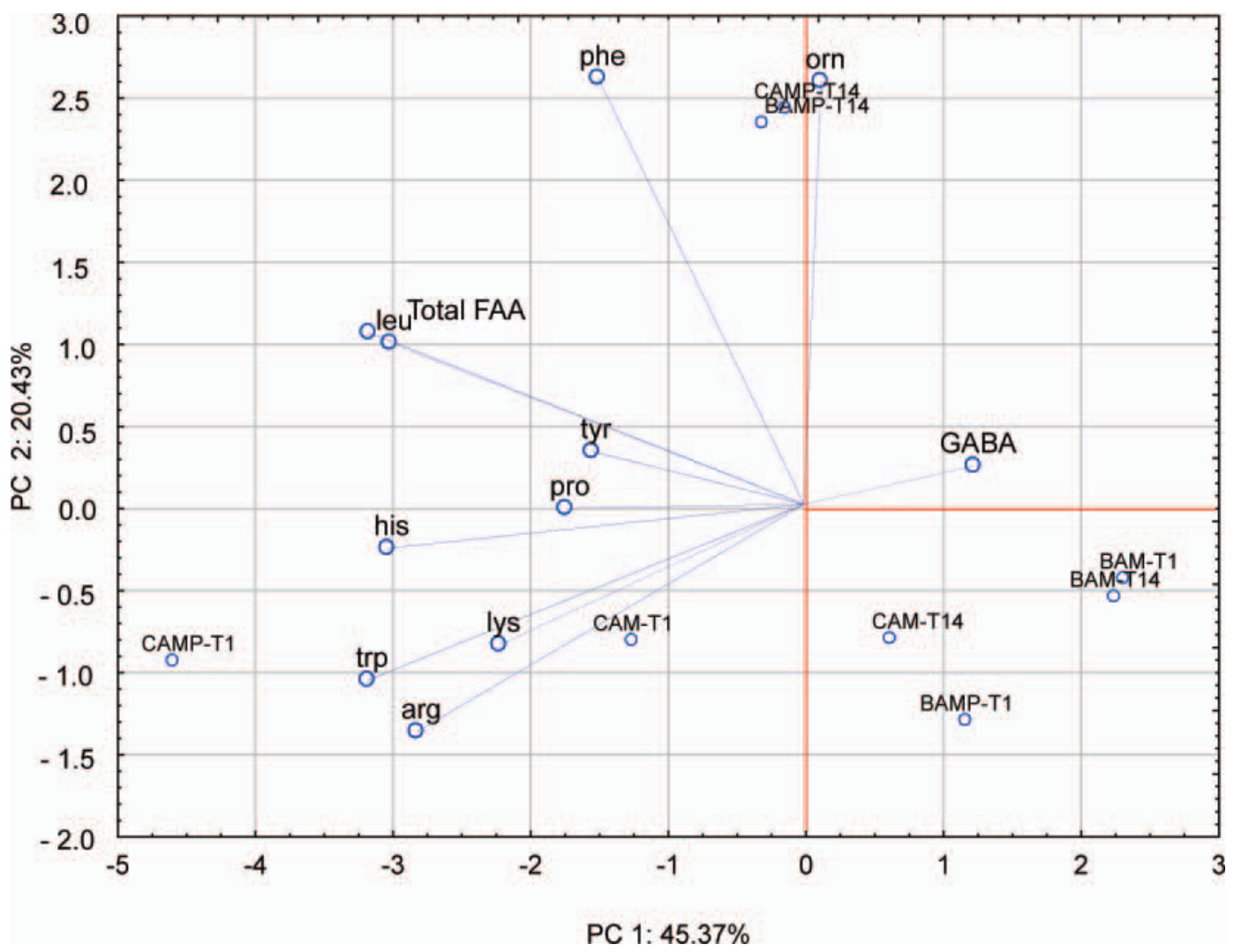

Figure 4. Score and loading plots of the first and second principal components (PC) after principal component analysis (PCA) based on the individual and total free AA (FAA) of Fior di Latte cheeses manufactured using chemical acidification with lactic acid (CAM), chemical acidification with lactic acid and addition of selected probiotic lactobacilli strains (Lactobacillus delbrueckii ssp. bulgaricus SP5 and Lactobacillus paracasei BGP1; CAMP), biological acidification with commercial starter culture (Streptococcus thermophilus; BAM), or biological acidification with commercial starter culture and addition of selected probiotic lactobacilli strains (SP5 and BGP1; BAMP) after 1 (T1) and 14 (T14) d of storage at $4^{\circ} \mathrm{C}$. Total FAA $=$ concentration of total free AA; GABA $=\gamma$-aminobutyric acid. Color version available in the online PDF.

being characterized by the lowest concentrations of FAA. During storage, no qualitative and quantitative variations in FAA were found for BAM cheese (at d 1 and 14). Cheese samples made with selected probiotic lactobacilli (CAMP and BAMP) were clearly separated from the others after $14 \mathrm{~d}$ of storage by higher concentrations of Asp, Phe, and Orn compared with the other cheeses.

\section{Sensory Analysis of Fior di Latte Cheese}

The sensory characteristics of the 4 types of Fior di Latte cheeses were determined during $14 \mathrm{~d}$ of storage at $4^{\circ} \mathrm{C}$ (Figure 5). At $1 \mathrm{~d}$ of storage, BAM received a higher score for flavor, sour, creamy, and body/texture attributes compared with CAM cheeses. Overall, cheeses with the addition of selected probiotic lactobacilli showed higher scores for all attributes compared with cheeses without addition of probiotics (CAMP and BAMP vs. CAM and BAM). As expected, a decrease in sensory attribute scores was found after 14 d of storage for all cheeses. Nevertheless, the highest scores were always found for BAM, CAMP, and BAMP cheeses. Bitterness was not found in any of the cheeses throughout $14 \mathrm{~d}$ of storage (data not shown).

\section{DISCUSSION}

Cheeses, and fresh cheeses in particular, are considered useful substrates for developing new probiotic foods (Cruz et al., 2009) because of the ability of cheese to improve survival of probiotic bacteria under gastrointestinal conditions (Fortin et al., 2011).

This work aimed to select and use heat-resistant probiotic lactobacilli in the manufacture of Fior di Latte cheese. Probiotic strains were chosen from among the Lactobacillus species (L. casei, L. delbrueckii ssp. bulgaricus, L. paracasei, L. plantarum, L. rhamnosus, and $L$. reuteri) usually found in natural whey starter cultures for making Fior di Latte cheese. This might guarantee desirable rheology and sensory characteristics of the cheese (de Candia et al., 2007). The capacity of the 


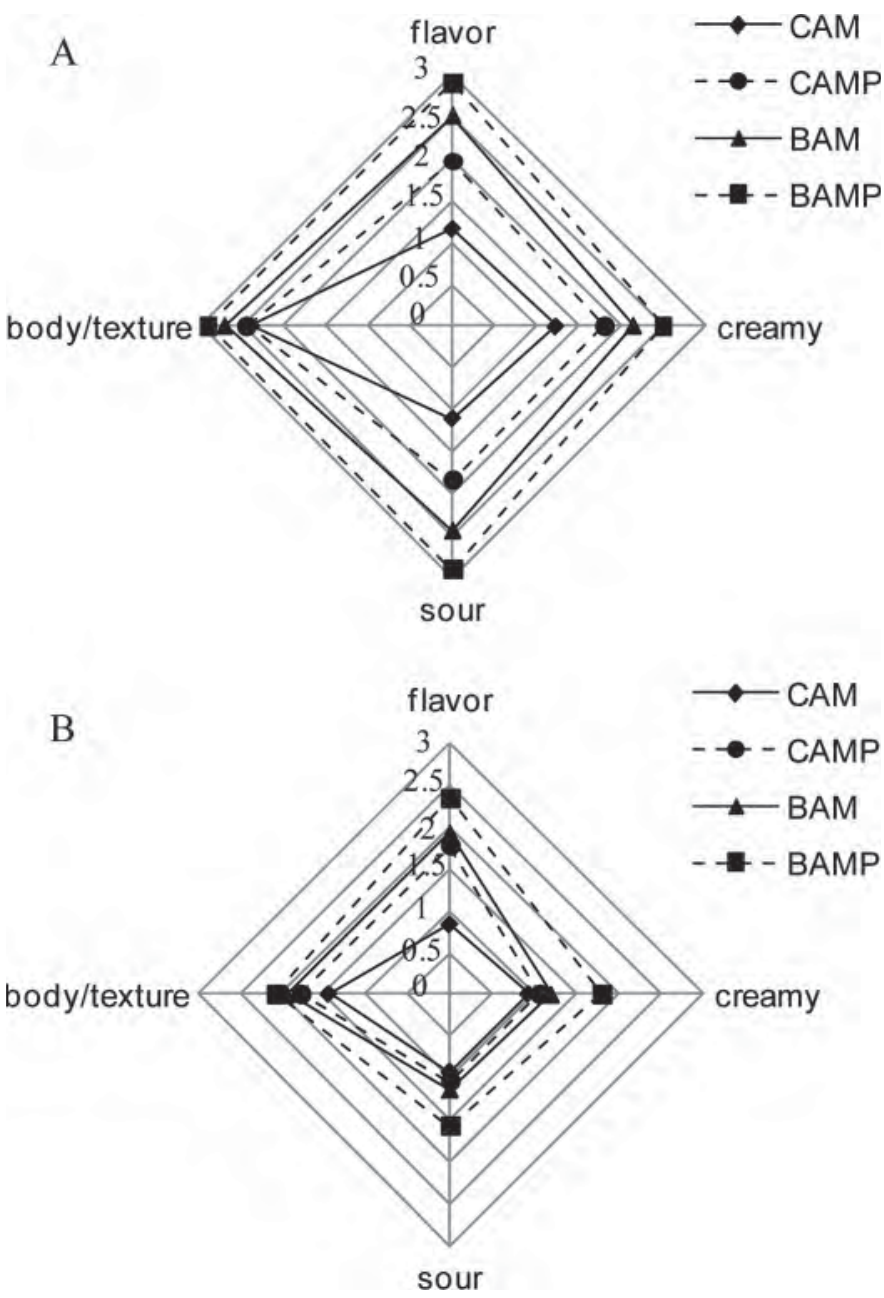

Figure 5. Sensory analysis of Fior di Latte cheeses manufactured using chemical acidification with lactic acid (CAM), chemical acidification with lactic acid and addition of selected probiotic lactobacilli strains (Lactobacillus delbrueckii ssp. bulgaricus SP5 and Lactobacillus paracasei BGP1; CAMP), biological acidification with commercial starter culture (Streptococcus thermophilus; BAM), or biological acidification with commercial starter culture and addition of selected probiotic lactobacilli strains (SP5 and BGP1; BAMP) after 1 (A) and 14 d (B) of storage at $4^{\circ} \mathrm{C}$.

18 probiotic strains to withstand heat treatments $(65$ or $55^{\circ} \mathrm{C}$ for $10 \mathrm{~min}$ ) varied markedly. Survival of strains tested in this study was comparable to that reported in literature for other lactobacilli subjected to similar heat treatments (De Angelis and Gobbetti, 2004). Overall, improved viability is achieved upon exposure to sublethal stresses (e.g., acid, bile, oxygen, cold, or heat), which enhances cell resistance during industrial processing and gastrointestinal transit (De Angelis and Gobbetti, 2004). For instance, pre-exposing Bifidobacterium adolescentis to $47^{\circ} \mathrm{C}$ for 15 min before lethal heat shock increased heat tolerance by 128 -fold (Schmidt and Zink, 2000). Increased tolerance to $55^{\circ} \mathrm{C}$ for $10 \mathrm{~min}$ was also found for adapted $\left(42^{\circ} \mathrm{C}\right.$ for $\left.30 \mathrm{~min}\right)$ probiotic lactobacilli cells. Heat-adapted L. delbrueckii ssp. bulgaricus SP5 ( $\mathrm{D}_{55}$ value of $\left.227.4 \mathrm{~min}\right)$ and $L$. paracasei BGP1 ( $\mathrm{D}_{55}$ value of $40.8 \mathrm{~min}$ ), which showed the highest resistance to heating conditions that mimicked curd stretching, were used for making Fior di Latte cheese. The addition of probiotics was done under technology conditions that included chemical or biological (Strep. thermophilus) acidification.

Although the curd had been stretched by treatment with hot $\left(80^{\circ} \mathrm{C}\right)$ water for $10 \mathrm{~min}$, cheeses added with probiotics or produced through biological acidification had cell numbers of presumptive lactic acid bacteria markedly higher than high-moisture chemically acidified Fior di Latte cheese. Similar cell densities of presumptive lactic acid bacteria were found in Mozzarella cheese made by using selected natural whey starter cultures (De Angelis et al., 2008). Because the heat resistance of some nonstarter lactic acid bacteria is well known (De Angelis and Gobbetti, 2004), presumptive lactic acid bacteria found at lower numbers in CAM may have been present in the milk and survived pasteurization. In agreement with previous studies (Iyer et al., 2010), the addition of probiotic lactobacilli appeared to increase survival of Strep. thermophilus. Even though the milk had been pasteurized and the curd treated with water at $80^{\circ} \mathrm{C}$, the number of coliforms was relatively high in CAM cheese $1 \mathrm{~d}$ after manufacture. During storage, the number of coliforms increased in all cheeses. Similar findings have been reported in previous studies on highmoisture Mozzarella cheese (De Angelis et al., 2008; Sinigaglia et al., 2008). As determined by RAPD-PCR and 16S rRNA gene analyses, CAMP or BAMP Fior di Latte cheeses contained both selected probiotics $(L$. delbrueckii ssp. bulgaricus SP5 and L. paracasei BGP1) at cell densities $\left(8.0 \log _{10} \mathrm{cfu} / \mathrm{g}\right)$ above the minimum required for food and beverages containing probiotic bacteria (Talwalkar et al., 2004; Jayamanne and Adams, 2006). Both strains showed high survival $\left(8.0 \log _{10}\right.$ $\mathrm{cfu} / \mathrm{g}$ of cheese) during $14 \mathrm{~d}$ of storage at $4^{\circ} \mathrm{C}$. Their viability was not affected by the presence of the starter Strep. thermophilus. Similar results were found for Bifidobacterium longum during manufacture of Cheddar cheese (Fortin et al., 2011). Although the RAPD-PCR and 16S rRNA gene analyses were successfully applied in this study as well as in others (Baruzzi et al., 2000; De Angelis et al., 2008), techniques (e.g., strain-specific probes for real-time PCR or fluorescent in situ hybridization; Saito et al., 2004; Kaur and Bhatia, 2008) that specifically detect SP5 and BGP1 would be desirable for rapid enumeration of the selected strains in Fior di Latte cheese. The protocol used in this work can be applied to other pasta filata cheeses using constitutively heat-resistant thermophilic probiotics instead of adapted cells of lactobacilli, because adaptation to high 
temperature is a reversible mechanism of resistance (De Angelis and Gobbetti, 2004).

When probiotic strains are selected for production of functional foods, they must maintain an elevated cell viability before consumption and they must not be detrimental to sensory (e.g., texture, color, flavor) attributes. Addition of bifidobacteria to Gouda (Gomes et al., 1995) and cottage (Blanchette et al., 1996) cheeses had a negative effect on cheese flavor because the concentration of acetic acid was too high and proteolysis too extensive, which decreased consumer acceptability compared with traditional cheeses. In the current study, chemically acidified Fior di Latte cheeses with or without addition of probiotics had the lowest concentration of protein and fat and the highest level of moisture. The same level of moisture was found in other chemically acidified Mozzarella cheeses (De Angelis et al., 2008). During storage, the $\mathrm{pH}$ of cheeses remained stable (chemically acidified cheeses) or increased slightly $(P<0.05$; biologically acidified cheeses with or without probiotics), whereas the $\mathrm{pH}$ of chemically acidified cheese with probiotics decreased. These differences could be related to the variation in cheese buffering capacities as the consequence of the concentration of calcium and the production of lactic acid by lactic acid bacteria (De Angelis et al., 2008). Primary and secondary proteolysis affects stretch, melt, flavor, and cook color of nonripened Mozzarella cheese as well as curd structure during refrigerated storage. Although some differences were found between samples in the current study, all cheeses showed hydrolysis of both $\alpha_{\mathrm{S} 1}-\mathrm{CN}$ and $\beta$-CN due to the activity of chymosin and plasmin, respectively; the RP-HPLC profiles differed between cheeses. The influence of probiotic lactobacilli on cheese proteolysis has been studied in different cheese varieties (Ong et al., 2007; Bergamini et al., 2009). Overall, secondary proteolysis as affected by probiotic cultures may markedly vary depending on the strain and cell density (Bergamini et al., 2009). Thermophilic lactobacilli such as L. delbrueckii ssp. bulgaricus have a more intense proteolytic activity than Strep. thermophilus. Mesophilic lactobacilli such as $L$. paracase $i$ are characterized by elevated peptidase activity (Gobbetti et al., 2007). After 14 d of storage, Fior di Latte cheeses made with the addition of probiotic strains were characterized by the highest levels of FAA, including Orn. Nevertheless, Arg decreased during storage of both these cheeses. The catabolism of Arg by the arginine deaminase pathway is a common mechanism of probiotic lactobacilli to survive during acid stress, starvation stress, or both (De Angelis and Gobbetti, 2004). In addition, FAA are the main factor responsible for the background flavor of cheeses and contribute, as precursors, to the formation of volatile compounds that influence taste and aroma (Gobbetti et al., 2007). As shown by sensory analysis, the addition of selected probiotic lactobacilli improved the flavor of the respective Fior di Latte cheeses. Overall, no body/texture or bitter defects were found in cheeses containing selected probiotic lactobacilli.

Although further studies are needed to show the in vivo probiotic effect, Fior di Latte cheese should be considered a useful vector to permit the daily consumption of doses of viable probiotic bacteria at sufficiently high levels to benefit the host. The use of L. delbrueckii ssp. bulgaricus SP5 and L. paracasei BGP1 enhanced flavor formation and shelf life of Fior di Latte cheese.

\section{ACKNOWLEDGMENTS}

This work was partly funded by Ministero dell'Istruzione, dell'Università e della Ricerca (Rome, Italy, PRIN n. 20088SZB9B). The authors thank Sanguedolce S.r.l. (Andria, BT, Italy) for additional financial support.

\section{REFERENCES}

Bai, A. P., and Q. Ouyang. 2006. Probiotics and inflammatory bowel diseases. Postgrad. Med. J. 82:376-382.

Baruzzi, F., M. Morea, A. Maturante, and P. S. Cocconcelli. 2000 Changes in the Lactobacillus community during Ricotta forte cheese natural fermentation. J. Appl. Microbiol. 89:807-814.

Bergamini, C. V., E. R. Hynes, M. C. Candioti, and C. A. Zalazar. 2009. Multivariate analysis of proteolysis patterns differentiated the impact of six strains of probiotic bacteria on a semi-hard cheese. J. Dairy Sci. 92:2455-2467.

Bergamini, C. V., E. R. Hynes, A. Quiberoni, V. B. Suárez, and C. A Zalazar. 2005. Probiotic bacteria as adjunct starters: Influence of the addition methodology on their survival in a semi-hard Argentinean cheese. Food Res. Int. 38:597-604.

Blakesley, R. W., and J. A. Boezi. 1977. A new staining technique for proteins in polyacrylamide gels using Coomassie Brilliant Blue G250. Anal. Biochem. 82:580-582.

Blanchette, L., D. Roy, G. Bèlanger, and S. F. Gauthier. 1996. Production of cottage cheese using dressing fermented by bifidobacteria. J. Dairy Sci. 79:8-15.

Boyle, R. J., and M. L. Tang. 2006. The role of probiotics in the management of allergic disease. Clin. Exp. Allergy 36:568-576.

Bruhn, C. M., J. C. Bruhn, A. Cotter, C. Garrett, M. Klenk, C. Powell, G. Stanford, Y. Steinbring, and E. West. 2002. Consumer attitudes toward use of probiotic cultures. J. Food Sci. 67:1969-1972.

Candela, M., S. Maccaferri, S. Turroni, P. Carnevali, and P. Brigidi. 2010. Functional intestinal microbiome, new frontiers in prebiotic design. Int. J. Food Microbiol. 140:93-101.

Coppola, S., F. Villani, R. Coppola, and E. Parente. 1990. Comparison of different starter systems for water-buffalo Mozzarella cheese manufacture. Lait 70:411-423.

Corbo, M. R., M. Albenzio, M. De Angelis, A. Sevi, and M. Gobbetti. 2001. Microbiological and biochemical properties of Canestrato Pugliese hard cheese supplemented with bifidobacteria. J. Dairy Sci. 84:551-561.

Cruz, A. G., F. C. A. Buriti, C. H. B. Souza, J. H. F. Fariaa, and S. M. I. Saad. 2009. Probiotic cheese: Health benefits, technological and stability aspects. Trends Food Sci. Technol. 20:344-354.

De Angelis, M., A. Corsetti, N. Tosti, J. Rossi, M. R. Corbo, and M. Gobbetti. 2001. Characterization of non-starter lactic acid bacteria from Italian ewe cheeses based on phenotypic, genotypic and cellwall protein analyses. Appl. Environ. Microbiol. 67:2011-2020. 
De Angelis, M., S. de Candia, M. P. Calasso, M. Faccia, T. P. Guinee, M. C. Simonetti, and M. Gobbetti. 2008. Selection and use of autochthonous multiple strain cultures for the manufacture of highmoisture traditional Mozzarella cheese. Int. J. Food Microbiol. $125: 123-132$

De Angelis, M., and M. Gobbetti. 2004. Environmental stress responses in Lactobacillus: A review. Proteomics 4:106-122.

De Angelis, M., and M. Gobbetti. 2011. Pasta-filata cheeses. Pages 745-752 in Encyclopaedia of Dairy Science. 2nd ed. J. W. Fuquay, P. F. Fox, and P. McSweeney, ed. Elsevier Ltd., Oxford, UK.

De Angelis, M., S. Siragusa, M. Berloco, L. Caputo, L. Settanni, G. Alfonsi, M. Amerio, A. Grandi, A. Ragni, and M. Gobbetti. 2006. Selection of potential probiotic lactobacilli from pig faeces to be used as additives in pelleted feeding. Res. Microbiol. 157:792-801.

de Candia, S., M. De Angelis, E. Dunlea, F. Minervini, P. L. H. McSweeney, M. Faccia, and M. Gobbetti. 2007. Molecular identification and typing of natural whey starter cultures and microbiological and compositional properties of related traditional Mozzarella cheeses. Int. J. Food Microbiol. 119:182-191.

Falagas, M. E., G. I. Betsi, T. Tokas, and S. Athanasiou. 2006. Probiotics for prevention of recurrent urinary tract infections in women: A review of the evidence from microbiological and clinical studies. Drugs 66:1253-1261.

Fortin, M. H., C. P. Champagne, D. St-Gelais, M. Britten, P. Fustier, and M. Lacroix. 2011. Effect of time of inoculation, starter addition, oxygen level and salting on the viability of probiotic cultures during Cheddar cheese production. Int. Dairy J. 21:75-82.

Gardiner, G., C. Stanton, P. B. Lynch, K. Collins, G. Fitzgerald, and R. P. Ross. 1999. Evaluation of Cheddar cheese as a food carrier for delivery of a probiotic strain to the gastrointestinal tract. J. Dairy Sci. 82:1379-1387.

Gobbetti, M., A. Corsetti, E. Smacchi, A. Zocchetti, and M. De Angelis. 1998. Production of Crescenza cheese by incorporation of Bifidobacteria. J. Dairy Sci. 81:37-47.

Gobbetti, M., M. De Angelis, R. Di Cagno, and C. G. Rizzello. 2007. The relative contributions of starter cultures and non-starter bacteria to the flavour of cheese. Pages 121-156 in Improving the Flavour of Cheese. B. Weimer, ed. Woodhead Publishing Ltd., Cambridge, UK

Gobbetti, M., R. Di Cagno, and M. De Angelis. 2010. Functional microorganisms for functional food quality. Crit. Rev. Food Sci. Nutr. 50:716-727.

Gomes, A. M. P., and F. X. Malcata. 1998. Development of probiotic cheese manufactured from goat milk: Response surface analysis via technological manipulation. J. Dairy Sci. 81:1492-1507.

Gomes, A. M. P., F. X. Malcata, F. A. M. Klaver, and H. J. Grande. 1995. Incorporation and survival of Bifidobacterium sp. strain Bo and Lactobacillus acidophilus strain Ki in a cheese product. Neth. Milk Dairy J. 49:71-95.

IDF. 1970. Determination of dry matter content in whey cheese. Standard 58. International Dairy Federation, Brussels, Belgium.

Iyer, R., S. K. Tomar, T. U. Maheswari, and R. Singh. 2010. Streptococcus thermophilus strains: Multifunctional lactic acid bacteria. Int. Dairy J. 20:133-141.

Jayamanne, V. S., and M. R. Adams. 2006. Determination of survival, identity, and stress resistance of probiotic bifidobacteria in bioyoghurts. Lett. Appl. Microbiol. 42:189-194.
Kaur, P., and A. Bhatia. 2008. The recent developments in molecular techniques for the detection of probiotics: A review. Int. J. Probiotics Prebiotics 3:65-70.

Kramer, S., and S. C. Bischoff. 2006. Therapeutic possibilities of probiotics in antibiotic-related diarrhea. MMW Fortschr. Med. 148:28-30.

Kuchroo, C. N., and P. F. Fox. 1982. Soluble nitrogen in Cheddar cheese: Comparison of extraction procedures. Milchwissenschaft $37: 331-335$.

O'Flaherty, S., and T. R. Klaenhammer. 2010. The role and potential of probiotic bacteria in the gut, and the communication between gut microflora and gut/host. Int. Dairy J. 20:262-268.

O'Riordan, K., and G. F. Fitzgerald. 1998. Evaluation of bifidobacteria for the production of antimicrobial compounds and assessment of performance in cottage cheese at refrigeration temperature. J. Appl. Microbiol. 85:103-114.

Ong, L., A. Henriksson, and N. P. Shah. 2007. Proteolytic pattern and organic acid profiles of probiotic Cheddar cheese as influenced by probiotic strains of Lactobacillus acidophilus, Lb. paracasei, Lb. casei or Bifidobacterium sp. Int. Dairy J. 17:67-78.

Özer, B., Y. S. Uzun, and H. A. Kirmaci. 2008. Effect of microencapsulation on viability of Lactobacillus acidophilus LA-5 and Bifidobacterium bifidum BB-12 during Kasar cheese ripening. Int. J. Dairy Technol. 61:237-244.

Reid, G. 2008. Probiotics and prebiotics: Progress and challenges. Int Dairy J. 18:969-975.

Rolfe, V. E., P. J. Fortun, C. J. Hawkey, and F. Bath-Hextall. 2006. Probiotics for maintenance of remission in Crohn's disease. Cochrane Database Syst. Rev. 4:CD004826.

Saito, Y., M. Sakamoto, S. Takizawa, and Y. Benno. 2004. Monitoring the cell number and viability of Lactobacillus helveticus GCL1001 in human feces by PCR methods. FEMS Microbiol. Lett. 231:125-130.

Schmidt, G., and R. Zink. 2000. Basic future of the stress response in three species of bifidobacteria: B. longum, B. adolescentis and $B$. breve. Int. J. Food Microbiol. 55:41-45.

Sinigaglia, M., A. Bevilacqua, M. R. Corbo, S. Pati, and M. A. Del Nobile. 2008. Use of active compounds for prolonging the shelf life of mozzarella cheese. Int. Dairy J. 18:624-630.

Talwalkar, A., C. W. Miller, K. Kailasapathy, and M. H. Nguyen. 2004. Effect of packaging materials and dissolved oxygen on the survival of probiotic bacteria in yoghurt. Int. J. Food Sci. Technol. 39:605-611.

Vinderola, C. G., W. Prosello, D. Ghiberto, and J. A. Reinheimer. 2000. Viability of probiotic (Bifidobacterium, Lactobacillus acidophilus and Lactobacillus casei) and nonprobiotic microflora in Argentinean Fresco cheese. J. Dairy Sci. 83:1905-1911.

Vinderola, C. G., W. Prosello, F. Molinari, D. Ghiberto, and J. Reinheimer. 2009. Growth of Lactobacillus paracasei A13 in Argentinian probiotic cheese and its impact on the characteristics of the product. Int. J. Food Microbiol. 135:171-174.

Zeppa, G., L. Conterna, and V. Gerbi. 2001. Determination of organic acids, sugars, diacetyl, and acetoin in cheese by high-performance liquid chromatography. J. Agric. Food Chem. 49:2722-2726. 